\title{
Feminist Studies of Globalisation: Beyond Gender, Beyond Economism? Catherine Eschle1
}

\begin{abstract}
This article offers a distinctive mapping of the feminist literature on globalisation. Part I sets the "new wave" of debate in the context of long-standing feminist theorising and organisation around global power and politics, drawing attention to a growing focus on economic processes. Part II explores the marginalisation of feminist arguments within globalisation studies, pointing to the dominance of an economistic model of globalisation as a key factor. It also identifies a parallel feminist tendency to neglect non-feminist efforts to develop non-economistic analyses of globalisation. Part III seeks to pinpoint the originality of the contribution of feminism. Although the most obvious starting point for such an evaluation is an emphasis upon gender, the feminist contribution is not reducible to this. Feminists have integrated gender analyses into accounts of multiple, intersecting, relations of global power. They also offer distinctive analyses of the relation between the local and the global and the character of agency and resistance. The article indicates that the feminist response to economism yet remains incomplete. Nonetheless, it demonstrates that feminist insights pose a significant challenge to non-feminist accounts of globalisation and to those organising within and against global power relations.
\end{abstract}

\section{Introduction}

Academic and activist interest in globalisation continues to rise, including amongst feminists. However, feminist interventions on the topic remain marginalised. It is thus a surprise to stumble across an article by a pioneer of globalisation theory and his colleague that devotes space to gender and to feminist accounts:

Increasingly female academics and intellectuals are beginning to see that a feminine view of the global circumstance is desirable, indeed necessary. This has undoubtedly been facilitated in part by the increasing involvement of women in transnational organizations and the growth of a global women's movement ... The feminist discourse of globalization is much more concerned with what may be called the communal aspect of globality and globalization ... it contextualizes the male tendency to consider the global circumstance in solely economic or "world politics" terms. In sum ... there are different male and female discourses. ${ }^{2}$

Although any awareness of the gender dimensions of globalisation is to be welcomed, this statement by Roland Robertson and Habib Haque Khondker is out of kilter with most contemporary feminist arguments. For here we have a claim that there is a single feminist/female discourse on the topic of globalisation, that it emphasises the ways in which the world is a unified community, and that this emphasis reflects a feminine viewpoint and values. Such an elision of women, feminists and femininity ignores the debates that have raged amongst feminists for years about the relationships between biological sex, socialised gender traits, identity and feminist politics. It fails to recognise that many feminists are sceptical about the possibility of global community, emphasising instead a harsh reality of inequality, division and fragmentation. And it denies the fact that, as Marianne Marchand and Anne Sisson Runyan make clear, "[t]here is no one single feminist approach to global restructuring. Instead there are multiple feminist approaches". 3 
It is evident that Robertson and Khondker's argument is not grounded in a full awareness of existing feminist literature. ${ }^{4}$ Yet notwithstanding significant divergences between their account and feminist accounts of themselves, there is a significant point on which they converge, and that is an emphasis on the challenge posed by feminists to "solely economic" narratives of globalisation. Marchand and Runyan confirm that feminist arguments "reveal that the ontology or nature of global restructuring is far more complicated than economistic accounts of this phenomenon suggest". ${ }^{5}$ Economism is understood here as the analytical practice of assuming a priori that the functioning of the global economy is causal, even determining, of social and political phenomena like globalisation. I will argue below that economistic approaches are becoming increasingly dominant in globalisation studies; the extent of the feminist challenge to economism thus merits particular attention.

So what, exactly, do feminists tell us about globalisation that non-feminist and/or economistic approaches miss? Why are feminist voices neglected in much of the globalisation literature? These are not new questions and other surveys have sought to answer them. In this article, I offer my own, distinctive "mapping" of the feminist literature and its relation to non-feminist argumentation, aiming to highlight the mechanisms of maginalisation at work, the originality of feminist contributions, and the work feminists still need to undertake.

What follows is divided into three parts. Part I places recent feminist globalisation literature in the context of longstanding feminist discourses on and organisation against global power relations. This draws attention to the rising centrality of a shared critique of global economic structures which means, paradoxically, that feminist interventions resonate with the increasingly economistic focus of non-feminist globalisation debates. I say paradoxically, because Part II explores the relationship of feminist literature to globalisation debates more generally and suggests that growing economism plays a crucial role in the marginalisation of feminism. An a priori emphasis on the determining role of economic factors, in mainstream and more critical approaches to globalisation, functions to position feminist theorisations and resistances as superstructural or of secondary importance. This indicates the need for feminists to contest rather than affirm economism, which is indeed the stated aim of much the new wave of literature. However, I point here to the fact that feminists have thus far tended to align themselves with critical but still economistic frameworks and to neglect the challenge posed to economism by a more sociological, multidimensional approach which has some space for gender analysis, albeit robbed of its more critical purchase. I suggest that feminist globalisation studies add to such an approach in important ways.

This brings me to Part III, in which I seek to pinpoint exactly what is original and distinctive about the feminist contribution to our understanding of globalisation. The most obvious starting point for any such assessment is the feminist emphasis upon gender: the differential impacts of globalisation upon women and men and the ways in which gender identity and interests constitute globalisation in its current forms. This on its own is a significant contribution to our understanding of how globalisation operates. However, the feminist contribution goes beyond this: integrating gender into sophisticated accounts of the multiple, intersecting, structures and relations of global power and also offering nuanced analyses of the mutually constitutive relation between the local and the global and the complex character of agency and resistance. I argue that the feminist challenge to economism in globalisation studies remains incomplete. Nonetheless, feminist insights still pose a significant challenge to non-feminist accounts of globalisation and to those organising within and against global power relations.

\section{Feminist Interventions in the Global}


Feminists did not enter into academic debates about globalisation until the mid-1990s, a few years after such debates began, but publications have since mushroomed. ${ }^{6}$ This should not be taken to mean that a feminist concern with globalisation is entirely new. Rather, feminists have only recently adopted the label of globalisation as a key analytical category for their work. ${ }^{7}$ This discursive shift has gained feminists the opportunity to engage with the existing academic literature on globalisation. What is in danger of being lost is the fact that feminist analysis draws upon a much longer-standing tradition of engagement with global issues and global power relationships. An understanding of this tradition is important because it partly explains the status of economic issues in feminist studies of globalisation and also because it points to the close relationship of feminist academic theory to feminist organising.

Feminist organising has long had an international, and internationalist, dimension. The nineteenth century saw the emergence of many regional and intercontinental feminist alliances in Europe and the Americas, most famously crystallising around state-spanning issues of suffrage, temperance, war and peace, and culminating in a series of international congresses in the early twentieth century. ${ }^{8}$ This activity demonstrates awareness that relations and structures of power affecting women could operate in connected ways across state boundaries. However, such awareness was frequently limited by the replication of imperialist, racist attitudes and structures in the interactions of white western women with black and third world women in Europe, North America and beyond - with some important exceptions. Anglo-American anti-lynching activism, socialist internationalist feminist organising across Europe at the turn of the century, and subsequent anti-imperialist networking in Latin America, indicate that a proportion of early feminists made connections between gendered inequalities and the operations of capitalist and also racialised structures within and across states. 9

A second peak, or wave, of feminist organising and theorising around the global occurred in the 1970s and early 80s. This reflected a more general revitalisation of feminist activism and was shaped to a large extent by the UN Decade for Women and its accompanying global conferences. ${ }^{10}$ Understandings of global power and politics were again often compromised and highly contested. Significant splits between North and Southern women's groups emerged at the first two conferences, in part due to the efforts of many Northern feminists to separate out so-called women's issues, "perceived as common to all women independent of nationality, race, and class", from the messy and divisive realities of international politics more generally, in the form of debates about the New International Economic Order, Israel/Palestine and South Africa. ${ }^{11}$ Such a position emerged in part out of legitimate wariness of the efforts of national governments to hijack the conferences for their own ends. But it also reflected the limitations of dominant definitions of feminism - the liberal and radical frameworks prevalent in Europe and North America. Liberal feminists, focusing on achieving equal rights within the liberal democratic state, have tended to position divisions of race, class and nationality as symptomatic of unequal treatment and/or cultural backwardness, to be eradicated through the universalisation of fairer laws and processes of modernisation. ${ }^{12}$ Radical feminists see the fundamental and pervasive oppressions of gender as stemming from male control and denigration of female sexuality, bodies and reproductive capacities. They have tended to argue that divisions of race, class and nationality between women are male impositions, which women need to transcend by creating a shared sisterhood. ${ }^{13}$ While liberal frameworks underpinned longstanding women's lobbying groups at the UN, which indeed were rarely openly feminist at all and primarily concerned with the advocacy of shared interests, the new generation of organisations that emerged around the conferences were frequently more radical in orientation. They focused on issues such as global patterns of male violence, women's health and reproductive rights, and were concerned to create autonomous organisational and communications networks. ${ }^{14}$ 
Liberal and radical frameworks came under increasing attack as the Decade progressed. They were accused, in effect, of replicating the imperialist attitudes of an earlier era, by propounding as universal that which was really the perspective of relatively privileged women from the North, and by downplaying the existence of capitalist and racialised hierarchies from which those women benefited at the expense of poor, black and third world women. ${ }^{15}$ This critique was articulated most strongly by black and third world feminists, who drew in part on anti-imperialist, socialist ideologies found also in strands of European feminism, as well as on their own experiences within international politics, feminism and anti-racist or nationalist organising. The growing influence of these arguments within feminism was strongly linked to the fact that black and third world feminists were consolidating their own transnational organisational networks during the second half of the Decade and beyond, and were able to insist on a much higher-profile role at the final Decade conference at Nairobi and again, ten years on, in Beijing. ${ }^{16}$ In addition, such arguments gained resonance in the context of the worldwide economic crisis in the 1980s and the influence within feminism of postmodernist arguments about identity and difference. ${ }^{17}$

The result was a shift in global feminist frameworks during the 1980s. Two dimensions of this shift are of particular significance for my argument. The first was the foregrounding of global economic dynamics: it became widely accepted that these needed to be central to any inclusive and critical feminist analysis and, further, that contemporaneous economic processes and policies were having exploitative and destructive impacts on many women and men. Thus, for example, Deborah Stienstra charts the increasing centrality of development issues, and of a more critical perspective toward them, within transnational feminist organising over the UN Decade. ${ }^{18}$ The second dimension of the shift in global feminist frameworks was the much greater attention paid to the specificities and differences in the ways in which global economic processes played themselves out in national and local contexts, and in the form of resistances that arose in response. The latter can be seen as symptomatic of what Anne Phillips describes as an ongoing tension in feminism between universalist and particularist frameworks, with particularist frameworks becoming dominant in academic feminist analyses during the1980s. ${ }^{19}$ However, when set in the context of debates about transnational feminist organising, this shift to the particular appears incomplete and unstable. The fact that it occurred at the same time as a more general acceptance by feminists of the significance of global economic processes is clearly key. This ensured that "many Southern feminists, like their counterparts in the North, 'did not entirely relinquish the fascination of finding global explanations to the subordination of women". 20

Thus surveys like that of Susan Bergeron identify an "abundance of feminist research into the relationship between gender relations and the globalization of capital". ${ }^{21}$ Strictly speaking, most of this work does not use the concept of globalisation - indeed much of it was written before the concept became popularised in the early 1990s. However, there is no doubt that the ways in which global economic dynamics have been depicted mesh with what is now widely referred to as globalisation, albeit with a concern to expose the "narrative of eviction" that has erased the gender-specific consequences on women's lives. ${ }^{22}$ Further, strictly speaking, a significant proportion of such feminist analyses do not focus on "capital" or "capitalism" as such, although largely critical conclusions about the operations of capitalism may be drawn from them. One set of analyses focused on "development". This took the form of the emergence of the Women in Development (WID) and latterly Gender and Development (GAD) schools, the emergence of which was strongly associated with activism at UN conferences, as emphasised by Stienstra, and in which black and third world feminist groups like the scholarly network DAWN (Development Alternatives with Women for a New era) played a particularly key role. ${ }^{23}$ A related but somewhat distinct set of literature, highlighted by Bergeron, did indeed focus centrally on the policy and structural shifts in 
global capitalism from the 1980s, but discussed these predominantly using the terminology of "neoliberalism" or "structural adjustment". And both development studies and critiques of neoliberalism have fed into a third set of feminist literature, this time within the discipline of international relations. From the late 1980s/early 1990s, feminists in IR have striven to interrogate the gendered constitution and biases of the discipline and its subdiscipline of "international political economy". 24

It is out of these three sets of research and related activism that, from the mid-1990s, we see a distinctive new "wave" of global feminist frameworks emerging. ${ }^{25}$ This wave draws heavily upon prior literature but also moves beyond it. And it coincides with key developments in feminist organising. Transnational networking has become commonplace, with many feminist groups striving, with mixed success, to "mainstream" their critique within the international organisations responsible for pushing the globalisation agenda worldwide. Such feminist groups are also becoming increasingly formalised and bureaucratic, although there is a continuing effort to construct democratic, networked modes of interaction in which Southern women play a more central agenda-setting role. And in recent years, feminist groups, including DAWN, have been pushing hard to integrate their feminist critiques into the so-called "anti-globalisation movement". ${ }^{26}$ It is in this context that a new wave of global feminist thinking explicitly identifies globalisation as the source and site of debate.

\section{Globalisation Discourses and the Marginalisation of Gender}

I now want to map out the relationship between feminist and non-feminist studies of globalisation with a view to explaining why feminist arguments, including claims about the significance of gender, tend to remain marginal. Of course the literature on globalisation is highly diverse: just as it is mistaken to assume a monolithic feminist approach to globalisation, so it is with non-feminist approaches. If anything, there is more diversity in the latter: globalisation remains one of the most contested areas of contemporary academic and policy debate. However, it is possible to pick out some broad schools and trends, which helps to clarify where feminist approaches do or do not fit. One final qualification is necessary. The dichotomy between feminist and non-feminist discourses is a rather stark one, particularly given the foregoing emphasis on heterogeneity. As will become clear below, there has been an effort in some strands of the literature to incorporate feminist concerns. However, such an effort is not central to the project of the authors identified. Further, self-declared feminist literature on globalisation, as I will make clear in Part III, has some clear identifying characteristics that non-feminist literature does not share.

It is common to subdivide academic studies of globalisation into two sets of approaches, reflecting key differences of substantive focus and disciplinary location. Economic-political approaches are characteristic of the bulk of work on the topic in IR, development studies and economics: they focus on the integration of the global economy and the impact of this upon the nation-state and other political institutions. Cultural-social approaches are clustered in sociology, anthropology and cultural studies: they depict globalisation as constituted by intertwined economic, political and social forces but disciplinary proclivities tend to encourage a focus on processes and outcomes concerning culture and identity - migration, nationality, hybridity, etc. ${ }^{27}$ A further subdivision is made by Marchand and Runyan amongst proponents of cultural-social approaches: between homogenisers, emphasising cultural universals and integration, and heterogenisers, emphasising the interplay or mutual constitution of universal processes and localised cultural forms, and the resulting patterns of fragmentation, difference, and hybridity. ${ }^{28}$ David Held and colleagues offer a third possible set of distinctions, which is in effect a subdivision of the 
economic-political approach on the basis of different attitudes toward the extent of economic integration and its impact upon the state. Hyperglobalists believe that the impact is profound and irreversible, and that it is undermining state sovereignty and state power as traditionally understood. Sceptics argue that levels of international trade are currently similar to those found at the end of the nineteenth century and that most integration has been at the regional level. Further, they insist that states remain dominant over economic interaction and capable of regulating and even subverting current trends. Transformationalists argue that recent changes are more profound than sceptics allow but not irreversible or uni-directional as hyperglobalists assume. Globalisation is seen as complex, contradictory, unequal and contestable. Most states are not in control of globalisation processes but neither are they being killed off; rather they are being reshaped in significant ways. ${ }^{29}$

Finally, approaches to globalisation can be distinguished on the basis of their normative or political attitude to globalisation. According to Jan Aart Scholte, we can identify liberals, conservative sceptics, and critics. ${ }^{30}$ The first category draws attention to the obvious fact that much of the hyperglobalist literature, which accepts and, further, condones globalisation, is of a liberal orientation. It should be recognised that there are significant differences between the most ardent, neoliberal proponents of globalisation, who believe the opening up of markets will bring prosperity, harmonisation and peace, and the warier liberal institutionalists and welfare liberals, who insist that economic and political reform is necessary to curb the more unequal and destructive effects of market forces. ${ }^{31}$ Scholte's second category maps to a large extent on to Held et al.'s 'sceptics' identified above. Attention is drawn to the fact that analytical scepticism about the character and extent of globalisation tends to be rooted in social-democratic, nationalist or mercantilist political traditions that defend the state as the locus of legitimate political decision-making and the nation as the source of cultural authenticity. ${ }^{32}$ The third category of 'critics', according to Scholte, draws on postmodernism or marxism - I would add that specifically neo-gramscian reformulations of marxism have been particularly influential in IR. ${ }^{33}$ Critics in general believe that globalisation is profoundly damaging and exploitative, functioning to increase poverty, inequality, environmental degradation and conflict. States and interstate institutions are seen as bound up within and compromised by globalisation processes and thus the appropriate locus for political and cultural responses lies in localised communities and/or transnational activism. Interestingly, critics often share with liberal advocates an hyperglobalist analysis of the scope and extent of globalisation and an homogenising view of its cultural effects - although they clearly reject a neoliberal appraisal of all this as positive. The flowering of critical literature in the late 1990s has been paralleled by a much-remarked rise in social movement activism, and an accompanying activist-produced literature, targeting those processes and actors seen to be representative of globalisation and most harmful, from the World Trade Organisation to genetically modified food. ${ }^{34}$

Notwithstanding this diversity of perspectives, I would agree with Robertson and Khondker that "the most prominent current usage of the term 'globalization' is undoubtedly associated with the global expansion of the market economy". 35 Further, it is also commonly believed that "globalization means global homogenization .... When globalization is seen as an obliterating tidal wave, it is frequently represented in primarily economic or politicoeconomic terms-as a new form of economic and cultural imperialism, as Westernization, as Americanization."36 Or as Leslie Sklair puts it:

The approach to globalization that I put forward in 1990 argued that there was one dominant global system structured around the transnational corporations, a transnational capitalist class and the culture-ideology of consumerism. In the early 1990s it was not clear to everyone that this apparently one-sided 
conception of globalization was the most fruitful approach to take. However, by the beginning of the twenty-first century, in the aftermath of the battle of Seattle and many other challenges to capitalist hegemony, it is difficult to deny the centrality of the struggle between the forces for and against capitalist globalization .... globalization has come to be identified in the minds of most people with the capitalist system. ${ }^{37}$

Although the status of capitalism as such is more contested than Sklair allows, what we have here is a convergence on the assumption that there is now a dominant model of globalisation, one that I will call the economic-homogenisation model. As Robertson and Khondker insist, such a model is economistic, in that it positions economic dynamics as causal of what are seen as unidirectional developments in other domains.

Why and to what extent has this framework become dominant? Robertson and Khondker acknowledge that different disciplinary discourses of globalisation reflect different disciplinary interests but they also point to the "global ascendancy of economics and economists in politically influential national, international and supranational contexts [to the extent that] ... the discourse of economic globalization is extremely pervasive." 38 This is a claim about the hegemonic influence of the economics discipline. It needs further to be recognised that this discipline has in the last few decades become unified to an extraordinary extent around neoliberal, hyperglobalising orthodoxies, although some cracks in this consensus have appeared more recently. ${ }^{39}$ Amongst analyses with a more cultural disciplinary and substantive focus, work by homogenisers on mass commodification, westernisation, the "global village", "the end of history" and "macdonaldisation" has received significantly more popular attention than the musings of heterogenisers on postcoloniality and hybridity. ${ }^{40}$ This is quite possibly because such hyperglobalising analyses have generally been written in a significantly more accessible style than analyses of postcoloniality and the like. It may also be because they share a tendency to position the global economy as determining cultural shifts which resonates strongly with hegemonic economic frameworks. Those few heterogenisers who have gained more widespread attention, such as Samuel Huntington with his "clash of civilisations" thesis and Benjamin Barber with his argument about "Jihad vs McWorld", also share this underlying approach: cultural difference and particularity are positioned as responses to globalisation which is perceived in economic-homogenisation terms. ${ }^{41}$

Further, the rise of critical perspectives on globalisation feeds into and off the dominance of the economic-homogenisation model. Such a claim undermines the assertion by Marchand and Runyan that the "critical wave of literature on globalization ... is rejecting the narrow economistic and often unquestioning literature of the first wave". 42 It is necessary here to make a careful distinction between approaches that are critical of neoliberal economic orthodoxy with those that are critical of economism as such. It is my contention that a large proportion of critical voices on globalisation are the former but not the latter. They assume an economic-homogenisation model of globalisation - as a deliberate neoliberal policy and/or because it is the latest stage of capitalism - and it is against this that their critiques are directed. Thus Sklair, for example, insists that "the most important global force at the beginning of the twenty-first century is the capitalist global system. Transnational corporations provide the material base for a transnational capitalist classes that unquestionably dictates economic transnational practices and is the most important single force in the struggle to dominant political and culture-ideology transnational practices". ${ }^{43}$ Or consider a recent collection of analyses by Stephen Gill, which focuses on what he calls "capitalist globalisation": "This great transformation is associated with the intensification and extension of exchange relations and the mediation of social relations by money, a process that 
is largely shaped by the discipline of capital". ${ }^{44}$ Sklair and Gill are both marxists but neither subscribes to the more structurally-determinist versions of marxism. Sklair emphasises the role of economic, political and cultural practices and Gill uses a neogramscian framework that pays attention to the ideologies and institutions of civil society, and into which Gill has integrated Foucauldian insights on surveillance and disciplining as forms of power. Nonetheless, their analyses of globalisation remain economistic, in terms of their clear $a$ priori location of causality in economic relations, processes and actors.

Although it should be remembered that non-economistic poststructuralists and ecologists also lurk in the critical fold, the economistic tendencies of critical academic literature are reinforced by much activist discourse in the aftermath of what Sklair and others call "the battle of Seattle". Activist discourse too demonstrates variation in what is included under the label globalisation but there remains considerable convergence around the view that "the enemy" consists of the increasing power of corporations and of international financial institutions, and the neoliberal policies of trade liberalisation and privatisation propounded by the latter and from which the former benefit. ${ }^{45}$ Some activists then insist that they are not anti-globalisation as such but are instead opposed more specifically to neoliberalism, or to 'economic globalisation', or to 'globalised capitalism', and in favour of an alternative, more humane globalisation. ${ }^{46}$ This points to a differentiated approach to globalisation, which poses a challenge to economism as well as to neoliberal economic orthodoxy and which has affinities with feminist approaches, as we will see later. However, it is counteracted by a strand of movement organising that is influenced more directly by marxism, albeit of a more ad-hoc or structurally determinist variant than that found in academic-oriented texts. This strand links neoliberal economic developments structurally to the underlying processes of capitalism; globalisation is repositioned as the latest stage of capitalism; and the anti-globalisation movement is reoriented as the "anti-capitalist" movement, rooted in class conflict and struggle. ${ }^{47}$ Thus there is significant convergence in critical academic approaches to globalisation and activist discourse, contributing to the pervasiveness of economism..

An emphasis on the restructuring of the global economy is shared to a large extent by feminist interventions, albeit for different reasons, as outlined in Part I. So why then do feminist voices remain largely ignored in non-feminist debates? Why does the feminist concern with gender receive little if any attention?

There are several possible reasons. The first is that globalisation discourses reflect what feminists have convincingly identified as a pervasive male dominance and masculinist bias in academic and public life more generally. Feminists explain how this unequal situation arose and is maintained in ways too numerous to do more than touch on here: ranging from a philosophical critique of rationalist epistemology as predicated on white, western, masculine traits; to a sociological focus on the 'situational constraints' of childcare and domestic chores that prevent many women being fully integrated into public life; to a radical feminist analysis of the operations of global patriarchy, seen as a unified system of male dominance rooted in control of female sexuality and reproductive capacity. ${ }^{48}$ However it is explained, the fact of male dominance in academic and public life, including in globalisation studies, is hard to dispute. A second, more specific, reason for the marginalisation of feminist insights in globalisation debates could be found in the claim made by some IR scholars that international or global relations are gender-neutral. This is related to the assumption of the separateness of the international realm, challenged by theorists ranging from liberalism to poststructuralism; it has also been shown by feminist IR scholars to be rooted in a masculinist standpoint, functioning to reify male dominance of global process and render women invisible. ${ }^{49}$ In the wake of such sustained attack, the notion of gender-neutrality would seem much less tenable now but it is possible that it lingers on in the habit of some globalisation theorists to adopt a 
high level of abstraction from concrete human relations, as we will see below. A third possible reason for feminist marginalisation is the self-exclusion of feminists from mainstream international and global debates. ${ }^{50}$ As Robertson and Khondker claim, "there has been a strong tendency in some feminist circles to privilege the local and in fact to regard the discourse(s) of globalization as a masculine preoccupation". ${ }^{51}$ However, this claim is unconvincing. In Part I, I attempted to show that feminists have long engaged with global issues; that the shift to the particular in the 1980s was always incomplete; and that feminists have been developing at least since then analyses of phenomena associated with globalisation. They have been explicitly engaging with the discourse of globalisation since the mid-1990s, and are still rarely listened to.

There is a fourth possible reason for feminist marginalisation that has as yet received little attention. I propose that economism, more dominant than ever in non-feminist globalisation discourses, encourages resistance to feminist concerns. This is because an $a$ priori emphasis on the analytical priority of economic dynamics renders gender analysis, and feminist mobilisation, invisible, superstructural or secondary. It becomes very difficult to see that gender might be causal of globalising dynamics and, consequently, that feminist mobilisation challenging gender relations might be integral to reshaping globalisation. This is as true of critical interventions into globalisation debates as it is of neoliberal hyperglobalists. The latter abstract economic rationality and interaction from other domains of social life, naturalising them and seeing them as unavoidable imperatives, thus removing economic decision-making, and the gendered assumptions underpinning their economic model, from political debate. Critics and sceptics respond by attempting to resocialise and historicise economic processes. But marxist critics do so by positioning them as causally prior to all other social phenomena and, frequently, by locating possible resistance in subordinate classes. It is hardly controversial in feminist circles to point to the problems that this has posed historically for feminists: the gendered assumptions about human agency upon which it rests; the equation of feminist concerns about equality in struggle with bourgeois deviation; the consequent urging to subsume feminist movement in the larger struggle. ${ }^{52}$ Although many marxists and feminists have sought to expand marxist frameworks and integrate feminist concerns - with strategies ranging from analysis of the gendered relations of productive and reproductive labour, to "dual-systems" theory on the interconnection of capitalism with patriarchy 53 - the relationship between marxism and feminism has always been a troubled one. Thus it is perhaps rather surprising that feminist globalisation studies in academia have thus far focused their critical fire almost exclusively on neoliberal paradigms, tending to align themselves with critical approaches rather than to interrogate them. ${ }^{54}$ Academic feminist studies of globalisation might learn here from feminist activists who are involved directly in the movement against aspects of globalisation and who clearly recognise the need to struggle simultaneously on two fronts: against neoliberal economic orthodoxies and against a reductive economism in oppositional discourses and organisation. 55

Finally, it should be acknowledged that feminists are not alone in attempting to develop non-economistic accounts of globalisation and that there are other theoretical resources upon which feminists can draw. As Robertson and Khondker insist, the economichomogenisation model was preceded by the effort to theorise culture, difference, locality and resistance as integral to globalisation in complex ways. ${ }^{56}$ Although a large proportion of such work fits broadly within the cultural-social disciplinary focus outlined above, it also crosses disciplinary boundaries and is perhaps best defined as transformationalist or perhaps multidimensional. ${ }^{57}$ The latter term is helpful in drawing attention to the fact that thinkers like Robertson, Anthony Giddens, Anthony McGrew and David Held have long argued that globalisation is constituted by multiple social, economic, political and cultural forces. An insistence on multiplicity encourages sensitivity to the ways in which globalisation is not 
monolithic and its direction not predetermined. Stress is placed on the rising density and stretching of social relations across the globe, the reshaping of space and time, and the role of consciousness and reflexivity. Agency and resistance are neither eradicated nor placed outside globalization but theorised as an integral aspect of its dynamics. Localities are seen as constitutive of global dynamics as well as the other way round. 58

My purpose in drawing attention to this multidimensional approach to globalisation is to highlight the fact that the economic-homogenisation model is increasingly dominant but it is not uncontested in non-feminist literature. Further, the multidimensional approach is potentially more sympathetic than economistic frameworks, including critical ones, to feminist concerns. However, as my opening discussion of Robertson and Khondker indicated, feminist insights have not yet been taken on board. Robertson and Khondker make the contentious claim there is a single feminist discourse on the topic of globalisation and that this reflects the feminine viewpoint and values of unity and holism. In earlier work, Robertson acknowledges that the association of women with what he called the more "familial" and "environmental" aspects of globalisation is ambiguous in its origins and political ramifications, and he notes feminist dispute over the universality and potential emancipatory effectiveness of women's "difference". He also, briefly, refers to the role of "a diverse international women's movement and that movement's particular concern with the theme of "women and development"" as "relevant to, and a manifestation of, globalization".59 This is a welcome acknowledgement but the ramifications for women, feminists and globalisation remain under-theorised. Giddens has written extensively on issues of identity and intimacy, in which he engages with feminist writings and foregrounds issues of gendered power and (in)equality. 60 There are clear links to these concerns and his work on globalisation in the form of a common emphasis on the disruptive effect of detraditionalisation and disembedding mechanisms in the context of high modernity; the consequent erosion of boundaries between private and public, local and global; and the ensuing struggle to establish a more reflexive consciousness as the basis for relationships with others. But this analysis has its limitations, focusing as it does on the ontological preoccupations of relatively privileged western women and men and downplaying interconnections with the material structures and relations of power, including the restructuring of capitalism and the changing role of the state. ${ }^{61}$ Neither Robertson nor Giddens engages with the new wave of feminist work on globalisation. This could enrich the multidimensional framework in important ways. It is with this in mind that the next part explores this new wave, pointing to four key areas in which it makes a distinctive contribution

\section{Key Feminist Contributions to Globalisation Debates}

\section{Gendering Globalisation}

One of the central aims of feminist social analysis for decades has been to "bring gender in": to make gender, and particularly women, visible. The new wave of feminist globalisation literature can draw upon a wide range of feminist arguments to this end, of which feminist development studies and analyses of neoliberal shifts remain the most influential. Two main elements in these bodies of work have been repeatedly highlighted as of central relevance to the feminist study of globalisation. ${ }^{62}$ The first is a focus on the restructuring of production and labour by transnational corporations. As Saskia Sassen puts it, this has led to the "feminization of the proletariat" whereby "off-shoring manufacturing jobs under pressure of low-cost imports mobilized a disproportionately [young] female workforce in poorer countries which had hitherto remained largely outside the industrial".63 
Extensive work on so-called "global factories" in export-processing zones has been supplemented by analyses of the restructuring of agricultural labour and the post-fordist trend to "homeworking". 64 The second relevant element of longer-standing feminist research focuses on the ways in which neoliberal-influenced programmes aimed at restructuring the state have had differential impacts on women and men. The overwhelming impression from this literature is that privatisation of utilities and services has led to large-scale female unemployment, particularly, in east central Europe, and that the slashing of social spending and welfare programmes there and in other regions has tended increase women's unpaid domestic and caring labour. ${ }^{65}$ Feminist globalisation literature continues to extend debate on both of these interconnected political economy issues, reaching complex conclusions about the context-specific combinations of exploitative and also sometimes empowering effects upon different women in different areas. ${ }^{66}$

Longer-standing work on these two issues was pioneering because it exposed the effects of globalisation on women and men - on gendered subjects. This strategy remains extremely valuable but, as Marchand and Runyan make clear, the new wave of feminist accounts of globalisation take two crucial further steps:

... feminist perspectives and epistemologies move us from looking at the gendered effects of global restructuring to examining the effects of gender on global restructuring and the effects of global restructuring on gender. The latter inquiry causes us to rethink gender, revealing it as a highly unstable category and thereby enabling us to disrupt the scripts of globalization that rely on gender to dichotomize thought and action as well as naturalize and legitimize inequality. 67

In other words, the new wave of feminist literature emphasises that the impact of globalisation on gender is ambiguous and destabilising. It does not act on pre-gendered subjects but rather creates gendered subjects that are contradictory and shifting. For example, it has been argued that the restructuring and transnationalisation of the ex-socialist states in central and eastern Europe has opened up space for autonomous women's mobilisations to emerge which can expose and challenge the gendered exclusions of the restructuring process. ${ }^{68}$ Filipina migrant domestic workers gather regularly in central Hong Kong, thus subverting the public/private divide and its associated racial and gender hierarchies and providing a visible reminder to the host state of their presence. ${ }^{69}$ As well as this kind of destabilisation of and by women, there is some - as yet limited - work in the new wave of feminist literature which highlights the destabilisation of male roles and identity. For example, Charlotte Hooper exposes the continuities and changes in hegemonic masculinity as evident in the Economist magazine, whereby an emphasis on strength and rationality has been forced into softer and more informal modes by the rise of a feminised service sector, leading to hypermasculine retrenchment and moments of "gender anxiety" where women are perceived as dominant and threatening. 70

Marchand and Runyan indicate that recent feminist accounts not only examine the effects of globalisation on gender but also expose the effects of gender on global restructuring. This poses a particularly significant challenge to non-feminist discourses because it positions gender as causal of globalisation. One feminist strategy here is to investigate the gender make-up of global governance institutions, highlighting the limited extent of women's access to decision-making processes. ${ }^{71}$ There is also extensive analysis of the ways in which dominant neoliberal economic models incorporate masculinist biases, in terms of their reliance on a model of human nature which universalises culturally-specific 
and masculinist assumptions about economic rationality, and their focus on the productive or commodity-based economy at the expense of the informal, household, care-based economy. ${ }^{72}$ Another key feminist strategy involves exposing the gendered metaphors and language through which globalisation discourse is constructed and sustained. For example, Marchand and Runyan stress that it is through its presentation as an "irresistible" (masculine) force", penetrating virgin economies, that globalisation is naturalised. ${ }^{73}$

However, Susan Bergeron warns that a feminist focus on this masculinist global discourse can contribute to its reification and fears the construction of an oppositional, idealised feminine order. ${ }^{74}$ There are two ways in which this could happen. First a masculinised global is counterpointed to a feminised local. This is in effect to argue for the existence of the public/private division on a world scale, with the relegation of women and femininity to the privatised, excluded, local realm underpinning the dominance of men and masculinity in the global public. ${ }^{75}$ Robertson and Khondker imply that this is the view of feminist work that privileges the local, but their analysis erases the long history of feminist engagement with the global. Second, a feminine form of globalisation could be juxtaposed to a masculine one. This is the preferred strategy that emerges from Robertson and Khondker's account. However, I have found little feminist literature that juxtaposes masculine to feminine orders in a simplistic, idealised way. While Robertson and Khondker argued for the existence of a feminine vision of community in counterpoint to masculine economism, Kimberly Chang and L.H.M. Ling offer a more subtle and convincing strategy. They contrast a hypermasculine mode of "techno-muscular capitalism" (TMC), facilitated by the "hollowing-out" of the state, with a feminised "regime of labour intimacy" (RLI), policed by a vigorous, coercive state. The RLI is exemplified for Chang and Ling by the large-scale migration of Filipinas to fulfil insecure, poorly paid domestic service roles, thus freeing up the metropolitan middle classes for fuller integration into the more public, less place-bound, masculinised world of TMC. ${ }^{76}$ These are neither static nor naturalised male and female globalisations: rather, we are shown how there are multiple gendered globalisations which have context-specific ramifications, are socially constructed, and are locked into an intimate and hierarchical relationship with one another.

\section{Intersectional Approaches to Global Power}

Significantly, Chang and Ling's analysis also moves beyond a one-dimensional focus on gender, exposing the devastating effects of the sexualised, racialised and national hierarchies at play within globalisation. This kind of analysis is becoming increasingly common within feminism. Black and third world feminists in particular have argued influentially for a shift away from an exclusive "monist" focus on gender, or even a "parallelist" focus on gender and capitalism, in favour of "intersectional" analyses of the ways in which multiple sources and forms of power manifest themselves in context-specific ways. Such analyses balance an emphasis on the macro-level patterns of the interstate system, transnational racial and gender hierarchies, and global capitalist dynamics, with attention to their context-specific variations and interplay. ${ }^{77}$ The feminist literature on globalisation continues to develop this kind of approach to global relations and structures of power.

Chang and Ling offer just one example; there are many others. Thus Jahnavni Phalkey shows how globalised processes of modernisation and industrialisation have been mediated in the Indian context by the rise of hindu nationalist forms of populist organisation, hindutva, in which women are mobilised in key and often destructive ways against muslim communities. ${ }^{78}$ Seiko Hanochi explores the ways in which localised Japanese patriarchal systems have combined with postwar economic modernisation, the US militarisation of South East Asia and the strong yen of the 1980s "to produce socioeconomic conditions that 
favor the commodification of the female body in a master-and-servant relationship", and that have encouraged a surge in the trafficking of prostitutes into Japan. ${ }^{79}$

It is worth noting that feminist globalisation theorists have as yet tended to focus on the interplay of racialised, gendered and economic hierarchies. Other kinds of power and other aspects of globalisation may be still in need of attention. For example, Janet Kenway points to:

... a relative absence of sustained feminist accounts of the relationship between capitalism and new technologies and the changes in the economic, knowledge and management approaches which have arisen, in part at least, as a function of the application of new information and communications media. 80

It seems to me that the cultural effects and causes of globalisation also remain relatively unexplored. This is not to deny the existence of an extremely rich feminist literature on identity, nationalism, migration, religion and sexuality on which feminist analysts of globalisation could and sometimes does draw. However, I am aware of little work that gives a sustained account of the relationship between culture and globalisation from a feminist perspective. ${ }^{81}$ I suspect that this is due less to disciplinary preoccupations, given the explicitly multidisciplinary character of much feminist work, and more to the increasing centrality of global economic dynamics in feminist analysis and organising traced in Part I. Further, there is a convergence here with the growing dominance of the economichomogenisation model of globalisation across the field. To give just two examples: although Haleh Afshar and Stephanie Barrientos explicitly stress the "multidimensional" or "multiple" and contradictory nature of globalisation, their book opens with an emphasis on economic integration and chapters are organised into sections on economic and political dimensions. ${ }^{82}$ Cindi Katz makes a similar move using a different kind of language, claiming "globalization, of course, is just another way of saying and doing imperialism ... we are living in the shards of a Eurocentric but global capitalism". 83

Now I do not mean here to dispute the extent and significance of the global integration of the capitalist economy under neoliberal auspices, the enormous impact this has had on much of social and political life across the world, and the fact that for many people this impact has been exploitative and detrimental. Whether the terminology used is of neoliberalism, capitalism or imperialism, feminist accounts generally make the hierarchical, racialised and systematically exploitative nature of recent economic developments extremely clear. Further, as the account of feminist debates in Part I indicated, these patterns do have to be central to any account of global power if that account is to be inclusive and critical. But there is a danger here of feminists using terminology and categorisations unreflectively and in ways that slide towards economism: lumping too much into economic categories and neglecting the causal role, and possible contestation of capitalist forces, by other dynamics gendered and racialised hierarchies, cultural processes, political organisations. I have argued that the prevalence of such economism across globalisation studies helps to explain the marginal attention paid to gender analysis and feminist activism within that field. I am also concerned that a feminist lapse into economism will subvert the full development of intersectional analysis of globalisation.

So how are feminists to proceed in developing such analyses and simultaneously to retain a critical emphasis on the exploitative and divisive impact of recent economic developments? I suggest that the strategy currently adopted by many feminists is to use the label of globalisation as a synonym for such developments. It is thereby accepted that studies of globalisation are studies of the global economy, located squarely within the disciplines of 
economics or international political economy. In which case, of course, economic processes, their constitution and their impact, are the central analytical concern: the feminist contribution is to show how these are intersected in specific contexts by other forms of power. Such an approach need not be economistic as such, in it could involve an attempt to show how these other forms of power are constitutive of neoliberal economic developments. However, it is clearly difficult to maintain equal analytical weight on other forms of power if the economy is the main focus of concern and given the overwhelming influence of economism more generally. There is a cost in terms of the loss of the potential nuances of the globalisation concept and there is also a difficulty of logic: if globalisation is global economic power, how can we talk of other forms of power as globalised? This strategy, then, brings with it ambiguities and contradictions. It may be in danger of subverting the challenge to the economism that keeps feminism in a marginal status in globalisation studies.

I want to propose an alternative strategy, which involves detaching the concept of globalisation from the global economy. This is not to suggest that feminist studies of globalisation abandon or even downgrade economic analysis. Rather, it involves a more careful and explicit naming of economic processes: reasserting for capitalism the name it has gone by for centuries; clarifying the changing nature of imperialism; labelling the ideological and policy shifts over the last few decades as neoliberalism or capitalist restructuring. This then opens up the possibility that globalisation is an analytically distinct, if empirically related, phenomenon. This seems to follow the logic of the intersectional framework more rigorously. For one thing, the globalised character of multiple forms of power and social relationships can be acknowledged, including but not reducible to the economic. Such a strategy finds a parallel in one of the activist discourses outlined earlier, which rejects the label of "anti-globalisation" and insists rather that the movement is specifically against neoliberal or capitalist forms of globalisation, and in favour of alternative, more humane and democratic, forms of globalisation. Further, it is here that the multidimensional academic discourse becomes useful, with its insistence that globalisation should be understood in terms of the stretching of social relations over space, the compression of time and distance, and the reconfiguration of geography, locality and borders. On such a view, the relationship between globalisation and capitalism, or between globalisation and neoliberal restructuring, becomes something to be investigated rather than assumed.

This leads me back to my claim that the multidimensional discourse of globalisation offers space to the feminist concern with gender. However, feminist intersectional analysis also points to problems with the way this non-economistic discourse has developed thus far and it is at this point that a key contribution of feminism becomes clear. Most obviously, the feminist emphasis on pervasive transnationalised racial and gender hierarchies corrects what remains a significant substantive lack in the multidimensional approach. More generally, feminist analysis brings a critical awareness of hierarchies and relations of domination into a discourse that tends to characterise the multiple factors of globalisation in more pluralist terms as social realms or fields. Finally, the insistence that multiple relations and structures of power interact in context-specific ways pushes what remains a largely "god's-eye-view" 84 of globalisation to engage with and write from concrete, diverse local standpoints.

\section{Subverting the Local/Global Dichotomy}

The relationship between the local and the global has long posed conceptual problems for international and global studies. It should be acknowledged that the multidimensional literature on globalisation has made a significant contribution to the debate on this topic, conceiving of the possibility of mutual constitution in terms of "glocalisation" and "hybridity". 85 Nonetheless, such arguments tend to be formulated in universalist and abstract terms. The feminist intersectional framework outlined above brings with it a much stronger 
methodological impetus to pay attention to the operations of globalisation in specific local contexts and to be explicit about the location from which the author writes. This is reinforced by the more general normative feminist commitment to exposing how apparently abstract, gender-neutral processes of globalisation, and writing about globalisation, are embedded within material, gendered social relationships. As Sassen argues, "the dominant narrative concerns itself with the upper circuits of capital, not the lower ones; and particularly with the hypermobility of capital rather than place-bound capital". Her effort to expose the ways in which high finance and information industries are underpinned by a gendered and racialised division of labour within the offices of global cities shows that "secretaries are part of it, and so are the cleaners of the buildings where the professions do their work". ${ }^{86}$ Chang and Ling's account of the underpinning of techno-muscular capitalism by a regime of labour intimacy populated by Filipina migrants has a similar effect. Further, note Naomi Klein's high-profile account of the globalisation of branding processes, whereby transnational companies become increasingly detached from specific products and the manufacturing of those products by associating themselves instead with ideas and identities and by contracting out production. Klein begins her deconstruction of this process from her home in a converted Toronto textiles warehouse, then traces her own physical journey through the different geographical sites where women and men produce, sell, consume and resist branded goods. ${ }^{87}$ It is through an emphasis on location and embodiment that women are made visible as sites, sources and authors of globalisation.

As Freeman warns, there is a potential problem lurking here in the equation of the global with abstract, masculinised global forces, with women visible only at the local, feminised level. On my reading, most of the new wave of feminist literature on globalisation avoids such a problem. It does more than simply maintain a parallel focus on both the global and the local or insist on their mutual constitution: rather, it subverts the dichotomy by insisting on many globals and many locals, and by looking at the complex ways in which these interact in different ways in different contexts. This is particularly well-illustrated in Freeman's case study of Caribbean "higglers". The term refers traditionally to women traders in foodstuffs. Freeman applies it to the contemporary phenomenon of professional women working in high-status managerial roles in globalised, feminised, offshore informatics industries. Such women frequently use the free flights that come with the job to engage in international higglering, venturing into a previously masculine world of international travel and leisure in order to bring back fashion and consumer goods with which they can increase their status and incomes. In so doing, they transnationalise a local feminine-associated practice and bring globalised feminine modes of consumption back to the local; they turn consumption into a form of production; and they translate taste and style across state boundaries. Freeman concludes that such women are not simply local actors, responding to global forces; rather "they are involved in crafting multiple modes of global capitalism itself". 88

\section{Reclaiming Agency, Reconstructing Activism}

Freeman goes on to claim that this process of transnational trading transforms the higgler "from being primarily instrumental in the forces of globalization (as an employee of an MNC) to becoming agentive". ${ }^{89}$ Her article offers an excellent demonstration of the fact that feminist deconstruction of the global/local dichotomy is accompanied by a move to bring agency centre-stage in accounts of globalisation. In part, this is a reaction to earlier WID and GAD representations of women as "one of the 'vulnerable groups' bearing the brunt of structural adjustment ... victims of a process of restructuring which is outside of their reach and by which they are increasingly marginalised and excluded". 90 
The concern to counter structural determinism is, again, not uniquely feminist. Others have pointed to the ideological character of the depiction of globalisation in terms of structures without actors - an irresistible force, for which no-one can be held accountable. Marxist-influenced critiques have exposed the class interests served by globalising dynamics in the economy, and the transnational class networks that promote them and which, in some cases, have the capacity to resist them. ${ }^{91}$ Those of a more social-democratic, sceptical inclination have insisted that states drive globalisation and thus could restructure or resist it. ${ }^{92}$ Note that such strategies limit agency to either class or states. A more open-ended approach is found in multidimensional accounts of globalisation, which have drawn on "structurationist" arguments to emphasise the constitutive role of global consciousness and reflexivity. Feminist work points to problems with all these approaches. Although some feminist analysis has followed the sceptical emphasis on state agency, emphasising the emancipatory potential of the state to act on behalf of women adversely affected by neoliberal restructuring, this is tempered by a longstanding feminist critique of the masculinist biases of the state and Bergeron, for one, has been critical of any romanticisation of the state in conditions of globalisation. ${ }^{93}$ Multidimensional accounts of agency have been criticised by Chang and Ling for privileging hegemonic masculine modes of subjectivity associated with the "globe-trotting cosmopolitan". 94

The new wave of feminist interventions are distinctive in their focus on how agency and subjectivity are gendered, and in their attention to the agency of women, particularly less privileged women. Their analyses create the space for this in ways already indicated above: by denaturalising global capitalism, pointing to the complex and often contradictory ways in which it interacts with other forms of power and local contexts to disrupt gender relations and to produce emancipatory as well as oppressive opportunities and effects for women.

A good deal of the literature emphasises women's resistances. 95 There are some problems with this emphasis as it can reduce agency to a function of structure, with commentators adopting an implicit foucauldian approach in which power calls forth its own resistances, rather than seeing agency as potentially generative. Also, the language of resistance may be in danger of imposing a shared, progressive orientation onto diverse actions. Phalkey's nuanced exploration of women's participation in communal violence in India enters a plea against dismissing such actions as false consciousness. "If women's agency in hindutva is a result of manipulative politics, it still has the potential for change". 96

Further, the language of resistance misrepresents a whole swathe of everyday actions and strategies that are not necessarily aimed at social change at all. Significantly, Chang and Ling move away from the language of resistance in their account of the experience of Filipinas overseas. Such women resort to a range of strategies to subvert their sexual stereotyping, ranging from a reversion to traditionalist notions of religion and nation, to the adoption of a sexually ambiguous "tomboyism" which enables intimate relationships with other Filipinas and the assumption of leadership roles. For Chang and Ling, this points to a "pragmatic globalism", which "aims to engage with, fit in, sort through, and negotiate across differences" and which "aspires for an overall sanity that endures through all the conflicts and contradictions that beset our daily, global life". 97 Neither transcendence nor resistance, then, but a creative coping strategy. Freeman makes a stronger claim for women's generative agency. In the process of transnational trading, the Barbadian higgler becomes "a new agent of globalization ... she is involved not in 'countering' global capitalism ... but in intensifying its reach and in a sense democratizing its rewards". 98 Here Freeman is explicit that higgler women are not resisting globalisation, nor simply responding to it, but making it their own.

Higglers are also agents of change in gender relations, albeit not in terms that are necessarily self-identified as feminist. The new wave of feminist globalisation analysis is keen to uncover spaces and potentialities for feminist organising but also highly critical of the 
universalisation of the labels or categories of feminism. The literature strives to use the diverse forms of agency exposed in rich case studies less to reaffirm feminist politics than to interrogate them. Taking context, diversity and agency seriously means abandoning any residual claim to a unified, authentic, singular feminist project. This feeds into and off the current trend to decentre white, western feminism and to emphasise the fragmentation and multiplicity of feminist organisation and subjectivity. And yet few feminist analysts would want to abandon the possibility of feminist politics altogether. This is perhaps particularly the case amongst feminist globalisation theorists, who have shown how globalisation is inscribed with macro-level patterns of inequality and domination that stretch across borders. Thus we find a number of pieces that explore the interplay of the fracturing of feminist politics with the transnationalisation of mobilisation in response to and as part of globalisation.

For example, Stienstra examines the role of women's caucuses in the UN conferences of 1992-1996, highlighting the growing leadership role of Southern women but also the continued conflicts caused by de facto geographical and financial dominance of Northern women. ${ }^{99}$ Amy J. Higer emphasises the impact of such a strategy on the 1994 Cairo population conference, asserting that what she calls the women's lobby "was more organised, politically knowledgeable and skilful than at any previous population conference", resulting in the high profile of women's rights in the final declaration. ${ }^{100}$ Like Stienstra, however, Higer emphasises the difficulties of maintaining a coalition along a north-south axis, pointing to the marginalisation of more radical southern groups with their emphasis on contesting structural adjustment policy. Kathleen Staudt et al. point out that access to the internet, which is becoming increasingly central to transnational mobilisation, is stratified by economic, gender and racial inequality. ${ }^{101}$ Valerie Sperling et al. offer a more positive analysis in their account of a US-Russian "transnational advocacy network" in which Russian women succeeded in shaping the agenda and in bringing non-economic resources which were vital for US women. "Despite the inequalities of such exchanges, we contend that, through the process of globalization, local movements learn from and build on each others successes". 102

All of these analyses reject the assumption, evident in idealised notions of global sisterhood, that feminism is somehow outside or transcendent of globalisation. They show how feminists are facing up to the multiplicity of globalised inequalities that structure and compromise feminist resistances. They also challenge dichotomised models of political action, by tracing the ways in which activists strive to build bridges between North and South, to mediate globality and locality, to avoid universalist erasure and particularist exclusion, by creating alliances that acknowledge differences and tackle inequalities. Clearly, feminists have some way to go in constructing such alliances. However, their experiences are of more general significance for the theorisation of activism and resistance in a global era. They are also of relevance to other movements. As many feminist activist groups are currently arguing, their analyses need to be taken on board more fully in the "antiglobalisation" movement if this is to provide an effective, radical challenge to the intersections of neoliberalism which gendered and racialised hierarchies, and if it is to be inclusive of those most affected by such intersections. ${ }^{103}$

\section{Conclusion}

This article began with the marginalisation of feminism in globalisation studies - and with a rare acknowledgement, by Robertson and Khondker, which nonetheless misrepresented feminist argument about globalisation in significant and curious ways. Robertson and Khondker correctly identified that the emergence of such feminist argument is closely connected to international feminist organising and that it poses a challenge to economism in globalisation discourses. However, they also asserted that the distinctive 
contribution of feminism lies in its elaboration of a feminine view of world community. Such an assertion is not borne out by a close study of the "new wave" of feminist literature on globalisation. In this article, I traced the emergence of this literature from long-standing feminist debates and organisation around global power, before exploring reasons for its marginalisation in non-feminist studies of globalisation, focusing in particular on the impact of the growing dominance of economism. I then offered a detailed mapping of what, exactly, the feminist literature has say to about globalisation that is original and distinctive - reaching very different conclusions from those of Robertson and Khondker.

The most obvious starting place for an assessment of the distinctive contribution of feminist studies of globalisation is their insistence on the significance of gendered inequalities. Feminists have been developing analyses of the gendered effects of the global economy for some decades now, emphasising particularly the detrimental effects of development and neoliberal restructuring on women. The new wave of feminist literature continues to build on these analyses and also to draw attention to the ways in which gender is being reconfigured by globalisation and the ways in which globalisation processes are themselves gendered. The latter presents a radical challenge to non-feminist discourses by positioning gender inequalities as constitutive. But it needs to be recognised that the feminist contribution goes beyond this emphasis on gender. Most feminist interventions adopt an "intersectional" approach to globalisation, paying attention to multiple globalised power relations, including gender, and to the ways in which they are played out in context-specific and often contradictory ways. This takes me to the concern of feminists to reconceptualise the relationship between the local and the global. Although others share this concern, feminists are distinctive in their consistent efforts to show how seemingly abstract global processes are embedded within local, gendered, relationships. They have also attempted to destabilise the global/local dichotomy by pointing to multiple globals and locals and the ways in which they are mutually constitutive. They look specifically to expose the ways in which women act to reconfigure global-local relationships in their daily lives. Thus, finally, feminists have attempted to recover possibilities for agency and resistance in a globalised era. Again, this attempt is not unique to feminism. But there is a distinctive emphasis here on the gendered and racialised specificities of agency and in the focus on the agency of women in diverse contexts. This has been accompanied by an interrogation of feminist movement politics in a global age, with particular attention paid to ongoing efforts to restructure transnational feminist activism in ways that recognise and counter the ways in which it is shot through by globalising dynamics of power and inequality. This carries lessons for other movements. In sum, the feminist contribution is not reducible to a focus on gender. It also involves complex arguments about global power, the global and local, and agency and resistance, which are at the cutting edge of critical interrogations of globalisation and which deserve fuller recognition.

However, I have also identified an ongoing tension or problematic in feminist studies of globalisation around the role of economic processes. Although it is correct to argue, as do Robertson and Khondker, that feminists have been critical of economism, I have also shown that a concern with global economic processes has become increasingly central to feminist theorising and organisation. There has resulted in a tendency to align feminist globalisation theory with the critical globalisation literature - which is critical of neoliberal economic orthodoxies but which remains economistic. I have argued that an economistic, economichomogenisation model of globalisation is increasingly dominant across globalisation studies and that this is a major reason why feminist concerns and insights remain marginal.

Economist approaches, whether supportive or critical of globalisation, do not allow a constitutive role for gender as a form of power or for feminism as a form of resistance. It is thus imperative that the feminist challenge to economism be developed more fully and on 
more fronts. Some hope can be drawn here from feminists involved in 'anti-globalisation' activism, which are explicitly attempting to challenge the economism of leftist oppositional discourses and practices. Academic feminist concerns could find some space in the noneconomistic, multidimensional approach as adopted by Robertson and Khondker, amongst others, although this often lacks a critical edge and its awareness of feminist arguments is yet limited. The feminist intersectional framework identified above can in some ways be interpreted as a fuller development of the multidimensional approach: it is more critical in its foregrounding of multiple power hierarchies, including gender; more contextually sensitive; and more embedded in the realities of diverse lives. Yet there appears to be some slippage in feminist studies of globalisation between this intersectional framework and the economistichomogenisation model. Certainly, the precise status of economic processes within the intersectional framework has not yet been fully worked out. I have suggested that feminists need to foreground the unequal operations of capitalism in globalisation, and in feminist mobilisations, whilst striving to avoid conflating current economic developments with globalisation per se. This is not simply a technical issue of terminology: it is crucial to the overall direction of academic analyses of globalisation and of activist efforts to challenge globalisation's most inhumane effects. Doubtless, the insights and dilemmas generated by feminist theory and practice will continue to shed light on the possibilities ahead.

\section{Endnotes}

1. I would like to thank Neil Stammers and the two anonymous reviewers appointed by Global Society for their detailed comments on earlier drafts of this article.

2. Roland Robertson and Habib Haque Khondker, "Discourses of Globalization: Preliminary Considerations", International Sociology, Vol. 13, No. 1 (1998), pp.37-38.

3. Anne Sisson Runyan and Marianne Marchand, "Conclusion: Feminist Approaches to Global Restructuring" in Marchand and Runyan (eds) Gender and Global Restructuring: Sightings, Sites and Resistances (London: Routledge, 2000), p. 226.

4. Robertson and Khondker claim that their generalisations come from their teaching of classes on globalisation and from a student's doctoral research on Thailand. This is intriguing and merits further research - Who, exactly, are they teaching? To what extent do young male and female students of globalisation have differing views about globalisation and why? To what extent might views in Thailand be distinctive to that country or region? It ought to be acknowledged that Robertson's earlier work does draw more extensively on published feminist literature; see below.

5. Runyan and Marchand, "Conclusion: Feminist Approaches to Global Restructuring", op. cit., p. 226.

6. E.g. Patricia M. Connelly et al. "Restructured Worlds/Restructured Debates:

Globalization, Development and Gender", Canadian Journal of Development Studies, Special Issue (1995), pp. 17-38; V. Spike Peterson, "The Politics of Identification in the Context of Globalization”, Women's Studies International Forum, Vol. 19, No. 1 (1996), pp. 5-15; Indiana Journal of Global Legal Studies, Special Issue, Vol. 4, No. 1 (1996); selected essays in Eleanore Kofman and Gillian Youngs (eds.), Globalization: Theory and Practice (London: Pinter, 1996); Haleh Afshar and Stephanie Barrientos (eds.), Women, Globalization and Fragmentation in the Developing World (Basingstoke: Macmillan, 1999); Mary K. Meyer and Elisabeth Prügl (eds.), Gender Politics in Global Governance (Lanham, Maryland: Rowman and Littlefield, 1999); Marchand and Runyan (eds.), Gender and Global Restructuring, op. cit.; Christa Wichterich, The Globalized Woman (London: Zed Books, 2000); Rita Mae Kelly et al. Gender, Globalization and 
Democratization (Lanham, Maryland: Rowman and Littlefield, 2001); Sheila Rowbotham and Stephanie Linkogle (eds) Women Resist Globalization: Mobilizing for Livelihood and Rights (London: Zed Books, 2001); Signs: Journal of Women in Culture and Society, Special Issue on Globalization, Vol. 26, No. 4 (2001); Feminist Review, Special Issue on Globalization, No. 70 (2002).

7. Marchand and Runyan prefer the term "global restructuring", as one way of jettisoning the ideological baggage of globalisation discourse. See "Introduction. Feminist Sightings of Global Restructuring: Conceptualisations and Reconceptualisations" in Marchand and Runyan (eds.), Gender and Global Restructuring, op. cit,. p. 7,. However their definition of "global restructuring" maps closely on to many definitions of globalisation and their critique focuses on self-declared globalisation literature.

8. See e.g. Leila J. Rupp, Worlds of Women: The Making of an International Women's Movement (Princeton: Princeton University Press, 19997); Deborah Stienstra, Women's Movements and International Organizations (Basingstoke: Macmillan, 1994), pp.43-59.

9. See the complex histories offered in Antoinette M. Burton, "The White Women's Burden: British Feminists and the Indian Woman 1865-1915", Women's Studies International Forum, Vol. 13, No. 4 (1990), pp. 296-308; Vron Ware, Beyond the Pale: White Women, Racism and History (London: Verso, 1992); Clare Midgley "'Anti-Slavery and the Roots of 'Imperial Feminism"' in Clare Midgely (ed.) Gender and Imperialism (Manchester and New York: Manchester University Press, 1998), pp. 161-179.

10. Irene Tinker and Jane Jaquette, "UN Decade for Women: Its Impact and Legacy”, World Development, Vol. 15, No. 3 (1987), pp. 419-427; Martha Alter Chen, "Engendering World Conferences: The International Women's Movement and the UN" in Thomas G. Weiss and Leon Gordenker (eds.), NGOs, The UN, and Global Governance (Boulder, CO: Lynne Rienner, 1996), pp. 139-155; Deborah Stienstra, 'Making Global Connections Among Women 1970-1999' in Robin Cohen and Shirin M. Rai (eds) Global Social Movements (London: Athlone Press), pp. 62-82.

11. Nilufer Çagatay et al. “The Nairobi Women's Conference: Toward a Global Feminism?”, Feminist Studies, Vol. 12, No. 2 (1986), p. 403. See also Tinker and Jaquette, "UN Decade for Women: Its Impact and Legacy", op. cit., pp. 420-422; Georgina Ashworth, "The United Nation's Women's Conference and International Linkages in the Women's Movement", in Peter Willets (ed.), Pressure Groups in the Global System (London: Pinter, 1982); Jessie Bernard, The Female World from a Global Perspective (Bloomington, IN: Indiana University Press, 1987), pp. 167-188.

12. On liberal feminism in general, see Zillah R. Eisenstein, The Radical Future of Liberal Feminism (New York: Longman, 1981); for a discussion of its application to international justice issues, see Mary-Kate G. Smith, "Is Western Liberal Feminism Bad for Women?", Labyrinth, vol. 3 (2001), available: <http://labyrinth.iaf.ac.at/2001/Smith.html\#_ftn1>

13. E.g. Robin Morgan (ed.) Sisterhood is Powerful: An Anthology of Writings From the Women's Liberation Movement (New York: Vintage, 1970) and Sisterhood is Global: The International Women's Movement Anthology (Harmondsworth: Penguin, 1985).

14. Stienstra, "Making Global Connections Among Women 1970-1999", op. cit., pp. 64-71. For an account of the growth of radical feminist organising at the transnational level, and of a shift to a more nuanced approach in the light of third world feminist arguments, see Charlotte Bunch, Passionate Politics: Feminist Theory in Action (New York: St. Martin's Press, 1987).

15. E.g. Chandra Talpade Mohanty, "Feminist Encounters: Locating the Politics of Experience" in Anne Phillips (ed.) Feminism and Politics (Oxford: Oxford University 
Press, 1998), pp. 254-272; bell hooks, Feminist Theory: From Margin to Center (Boston: South End Press, 1984).

16. E.g. Stienstra, "Making Global Connections Among Women 1970-1999", op. cit., pp. 7175; Helen I. Safa, "Beijing, Diversity and Globalization: Challenges to the Women's Movement in Latin America and the Caribbean", Organization, Vol. 3, No. 4 (1996), pp. 563-570; and Chen, op. cit., p. 142.

17. On the former, see Jeanne Vickers, Women and the World Economic Crisis (London: Zed, 1991); on the latter, see Linda Nicholson (ed.) Feminism/Postmodernism (London: Routledge, 1990).

18. Stienstra, "Making Global Connections Among Women 1970-1999”, op. cit., pp. 75-76.

19. Anne Phillips, "Universal Pretensions in Political Thought" in Michèle Barrett and Anne Phillips (eds) Destabilizing Theory: Contemporary Feminism Debates (Stanford, CA: University of Stanford Press), pp. 10-30.

20. Patricia M. Connelly et al., citing Virginia Vargas, op. cit., p. 28.

21. Suzanne Bergeron, "Political Economy Discourses of Globalization and Feminist Politics", Signs: Journal of Women in Culture and Society, Vol. 26, No. 4 (2001), p. 990.

22. Saskia Sassen, "Toward a Feminist Analytics of the Global Economy", Indiana Journal of Global Legal Studies, Vol. 4, No. 1 (1996), p. 10.

23. See Marchand, "Reconceptualising 'Gender and Development' in an Era of 'Globalisation"”, Millennium: Journal of International Studies, Vol. 25, No. 3 (1996), pp. 577-603, and Shirin M. Rai, Gender and the Political Economy of Development (Cambridge: Polity, 2002), Chapter 2, for accounts of WID and GAD. Kathleen Newland analyses the fraught relationship of WID to international organising during the UN Decade in "From Transnational Relationships to International Relations: Women in Development and the International Decade for Women", Millennium: Journal of International Studies, Vol. 17, No. 3 (1988), pp. 507-516. DAWN articulated their critique of dominant development paradigms in Gita Sen and Caren Grown, Development Crises and Alternative Visions: Third World Women's Perspectives (London: Earthscan, 1987).

24. For pioneering feminist IR texts, see Cynthia Enloe, Bananas, Beaches and Bases: Making Feminist Sense of International Politics (Berkeley, CA: University of California Press, 1990); Sandra Whitworth, "Gender in the Interparadigm Debate", Millennium: Journal of International Studies, vol. 18, No. 2 (1989), pp. 265-272; J. Ann Tickner, Gender in International Relations: Feminist Perspectives on the Achieving Global Security (New York: Columbia University Press, 1992); Christine Sylvester, Feminist Theory and International Relations in a Postmodern Era (Cambridge: Cambridge University Press, 1994); V. Spike Peterson and Anne Sisson Runyan, Global Gender Issues, $2^{\text {nd }}$ edition (Boulder, CO: Westview Press, 1999).

25. The use of "wave" terminology here is an intentional link to claims of a possible "third wave" of feminism and to Marchand and Runyan's identification of a "second wave" of globalisation literature.

26. On movement institutionalisation and mainstreaming see Deborah Stienstra, "Dancing Resistance from Rio to Beijing: Transnational Women's Organising and United Nation Conferences 1992-1996' in Marchand and Runyan (eds.), Gender and Global Restructuring, op. cit., pp. 209-224; Amy J. Higer, “International Women's Activism and the 1994 Cairo Population Conference" in Meyer and Prügl (eds.), op. cit., pp. 122-141; Robert O'Brien, Anne Marie Goetz, Jan Aart Scholte and Marc Williams. Contesting 
Global Governance: Multilateral Economic Institutions and Global Social Movements (Cambridge: Cambridge University Press, 2000), pp. 24-66. On 'NGO-ization' see Sonia Alvarez, "Advocating Feminism: The Latin American Feminist NGO 'Boom'”, International Feminist Journal of Politics, vol. 1, No. 2 (1999), pp. 181-209. On the parallel growth of the network form in feminist movement organisations, see Valentine Moghadam, "Transnational Feminist Networks: Collective Action in an Era of Globalization", International Sociology, vol. 15, No. 1 (1995), pp. 57-84. DAWN strategy on integration into the "anti-globalisation movement", primarily through engagement with the World Social Forum process, is discussed in Gigi Francisco, "Sighting Paradoxes for Gender in the Social Movements", available: $<$ http://ww.dawn.org.fj>; and Lisa Veneklasan, "Building Solidarity", DAWN Informs (April 2003), p.7.

27. Marchand and Runyan, "Introduction. Feminist Sightings of Global Restructuring: Conceptualisations and Reconceptualisations", op. cit., p. 3; compare, for example, the economic-political focus of Ian Clark, Globalization and International Relations Theory (Oxford: Oxford University Press, 1999); Paul Hirst and Grahame Thompson, Globalization in Question, $2^{\text {nd }}$ edition (Cambridge: Polity Press, 1999); and Leslie Sklair. Globalization: Capitalism and its Alternatives, $3^{\text {rd }}$ edition (Basingstoke: Palgrave 2002); with the cultural-social preoccupations of Michael Feathersone (ed.) Global Modernities: Nationalism, Globalisation and Modernity (London: Sage, 1990); Michael Featherstone, Undoing Culture: Globalisation, Postmodernism and Identity (London: Sage, 1995); Roland Robertson (1992) Globalization; Social Theory and Global Culture (London: Sage, 1990) and John Tomlinson, Globalization and Culture (Cambridge: Polity Press, 1999).

28. Marchand and Runyan, "Introduction. Feminist Sightings of Global Restructuring: Conceptualisations and Reconceptualisations", op. cit., p. 3, following Featherstone and Lash. Compare, for example, George Ritzer's The McDonaldization of Society, Revised edition (London: Sage/Pine University Press, 2000) with Arjun Appadurai, Modernity at Large: Cultural Dimensions of Globalization (Minnesota: University of Minnesota Press, 1996). Appadurai's work is also notable for his development of a multidimensional approach, explained in more length below: he attempts to bridge the disciplinary divide with a cultural-economy framework which delineates the operations of five distinct global flows or "scapes".

29. David Held, Anthony McGrew, David Goldblatt and Jonathon Perraton, Global Transformations: Politics, Economics and Culture (Cambridge: Polity Press, 1999), pp. 3-10; for hyperglobalists of very differing ideological perspectives, see Kennichi Ohmae, The Borderless World: Power and Strategy in the Interlinked Economy (London: Harper Collins, 1994) and Stephen Gill, Power and Resistance in the New World Order (Basingstoke: Palgrave, 2002), p. xii; the most widely cited sceptical work is probably Hirst and Thompson, op. cit.; the most high-profile of the transformationalists are probably Held and his colleagues - as well as Global Transformations, see Held, Democracy and the Global Order (Cambridge: Polity Press, 1995).

30. Jan Aart Scholte, "Beyond the Buzzword: Toward a Critical Theory of Globalization" in Kofman and Youngs (eds.), op. cit., pp. 49-53.

31. Compare Ohmae, op. cit., with the Commission on Global Governance, Our Global Neighbourhood (Oxford: Oxford University Press, 1995). This distinction between liberal perspectives on globalisation and global governance is elaborated in Andrew Hurrell and Ngaire Woods, "Globalisation and Inequality", Millennium: Journal of International Studies, vol. 24, No. 3 (1995), pp. 447-470 and Richard Falk, "Liberalism at the Global 
Level: The Last of the Independent Commissions?", Millennium: Journal of International Studies, vol. 24, No. 3, pp. 563-576.

32. E.g. Hirst and Thompson, op. cit.; Kenneth Waltz, "Globalization and Governance", PS Online (December 1999), available:

$<$ http://www.mtholyoke.edu/acad/intrel/walglob.htm>

33. E.g. Gill, op. cit.; Robert Cox, "Democracy in Hard Times: Economic Globalization and the Limits of Democracy" in Anthony McGrew (ed.) The Transformation of Democracy? Globalization and Territorial Democracy (Cambridge: Polity, 1997); several essays in Barry K. Gills (ed.) Globalization and the Politics of Resistance (Basingstoke: Palgrave, 2002); for a distinctive marriage of marxism and postmodernist modes of critical theorising on globalisation, see Micahel Hardt and Antonio Negri, Empire (Cambridge, Mas.: Harvard University Press, 2000). There are also critical elements in culturalhomogenisation texts such as Ritzer, op. cit.

34. E.g. Kevin Danaher and Roger Burbach (eds.), Globalize This! The Battle Against the World Trade Organization and Corporate Rule (Monroe, Maine: Common Courage Press, 2000); Naomi Klein, No Logo (London: Flamingo, 2000); Amory Starr, Naming the Enemy: Anti-Corporate Movements Confront Globalization (London: Zed Books, 2001); Emma Bircham and John Charlton (eds.), Anti-Capitalism: A Guide to the Movement, $2^{\text {nd }}$ edition (London: Bookmarks Publications, 2001); Robin Broad (ed.), Global Backlash: Citizens' Initiatives for a Just World Economy (Lanham, MD: Rowman and Littlefield, 2002).

35. Robertson and Khondker, op. cit., p. 25.

36. Robertson and Khondker, op. cit., pp.28, 31. Similar arguments about the prevalence of this economistic and homogenising assumption, from rather different perspectives, can be found in Martin Albrow, The Global Age: State and Society Beyond Modernity (Cambridge: Polity Press, 1996), chapter 4 and Martin Shaw, Theory of the Global State: Globality as an Unfinished Revolution (Cambridge: Cambridge University Press, 2000), pp.80-90.

37. Leslie Sklair, Globalization: Capitalism and its Alternatives, $3^{\text {rd }}$ edition (Oxford: Oxford University Press, 2002), pp. 1 and 4.

38. Robertson and Khondker, op. cit., p.36.

39. Mark Rupert, Ideologies of Globalization: Contending Visions of a New World Order (London: Routledge, 1999), Chapters 3 and 7; Robin Broad, "The Washington Consensus Meets the Global Backlash: The Shifting Debate over Development in Theory and in Practice", paper presented at the International Studies Association $44^{\text {th }}$ Annual Convention, (February 2003), Portland, Oregon, USA.

40. Witness the continuing influence and high profile of Marshall McLuhan (with Bruce R. Powers) The Global Village: Transformations in World Life and Media in the 21st Century, Reprint Edition (Oxford: Oxford University Press, 1998); Ritzer, op. cit.; Francis Fukuyama, The End of History and the Last Man (London: Hamish Hamilton, 1992).

41. Samuel Huntington, The Clash of Civilizations and the Remaking of World Order (London: Touchstone, 1998); Benjamin Barber, Jihad versus McWorld (New York: Times Books, 1996).

42. Marchand and Runyan, "Introduction. Feminist Sightings of Global Restructuring: Conceptualisations and Reconceptualisations",op cit., p. 7; following Kofman and Youngs. I note that Marchand and Runyan subsequently qualify this endorsement of 
critical literature by pointing to the fact that much of it, including neogramscian literature with its high-profile attempt to carve out a causal role for ideas and institutions, remains wedded to "materialist foundations", p. 8.

43. Sklair, op. cit., p. 9.

44. Gill, op. cit., p. xii.

45. E.g. Danaher and Burbach, op. cit., Starr, op. cit.; Broad, Global Backlash, op. cit.; Klein, Fences and Windows: Dispatches from the Frontline of the Globalization Debate (London: Flamingo, 2002) and websites of groups such as Peoples' Global Action, available <http://www.nadir.org/nadir/iniativ/agp/en/PGAInfos/manifest.htm>; the World Social Forum, available: <http://www.forumsocialmundial.org/>; or Globalise Resistance, available: <http://www.resist.org/about/standfor.html $>$.

46. E.g. David Graeber, "The New Anarchists”, New Left Review, No. 13 (Jan-Feb 2002), pp. 62-66; Klein, Fences and Windows, op. cit.; Danaher and Burbach, op. cit., Introduction.

47. E.g. Bircham and Charlton, op. cit.; Alex Callinicos, An Anti-Capitalist Manifesto (Cambridge, Polity, 2003).

48. For a selection of well-cited feminists texts surveying dominance and bias in society, politics, academia and the pursuit of knowledge from a range of perspectives, see Vicky Randall, Women and Politics: An International Perspective, $2^{\text {nd }}$ edition (Basingstoke: Macmillan, 1987); Sylvia Walby, Theorizing Patriarchy (Oxford: Basil Blackwell, 1990); Patricia Hill Collins, Black Feminist Thought: Knowledge, Consciousness and the Politics of Empowerment, $2^{\text {nd }}$ edition (London: Routledge, 2000); Ruth Lister, Citizenship: Feminist Perspectives (Basingstoke: Macmillan, 1997); Nira Yuval-Davis, Gender and Nation (London: Sage, 1997); Seyla Benhabib and Drucilla Cornell (eds) Feminism as Critique: Essays on the Politics of Gender in Late Capitalist Societies (Cambridge: Polity, 1987); Sandra Harding (ed.) Feminism and Methodology: Social Science Issues (Bloomington: Indiana University Press, 1987); Ann Garry and Marilyn Pearsall (eds) Women, Knowledge and Reality: Explorations in Feminist Philosophy (London: Unwin Hyman, 1989).

49. E.g. Tickner, op. cit., pp. 1-5; Sylvester, op. cit., pp. 4-9; Fred Halliday, Rethinking International Relations (Basingstoke: Macmillan, 1994), pp. 147-149.

50. Halliday, op. cit., p. 149.

51. Robertson and Khondker, op. cit., p. 37.

52. E.g. Lydia Sargent (ed.)Women and Revolution: A Discussion of the Unhappy Marriage of Marxism and Feminism (Boston: South End Press, 1981); Sheila Rowbotham, Lynn Segal and Hilary Wainwright, Beyond the Fragments: Feminism and the Making of Socialism (London: Merlin Press, 1979).

53. E.g. Friedrich Engels, The Origins of the Family, Private Property and the State (New York: International Publishers, 1972); Margaret Benston, "The Political Economy of Women's Liberation”, Monthly Review, vol. 21, No. 4 (1969), pp. 13-27; Iris Young, "Socialist Feminism and the Limits of Dual Systems Theory", Socialist Review, vol. 10, nos. 2-3 (1980), pp. 169-188.

54. As remarked by an anonymous reviewer of this paper, it is notable that many feminist theorists working in the field of international and global studies have been heavily influenced by the neogramscian framework - e.g, Marianne Marchand, Sandra Whitworth, Deborah Stienstra and Jacqui True. While these authors provide some critique of the limitations imposed by the "materialist foundations" of neogramscianism, 
see note 42 , a sustained feminist analysis of its analytical and political implications, particularly with regard to globalisation, has not yet been produced.

55. This duality of feminist struggle against neoliberal economic orthodoxy and the economic reductionism of oppositional activism is evident at several points in Klein, Fences and Windows, op. cit.; it is also evident on the websites of feminist groups heavily involved in the World Social Forum. See DAWN's World Social Forum Supplements available: $<$ http://www.dawn.org.fj/global/globalisation/socialforum.html $>$; or articles such as "Where Gender and Race Intersect", Dawn Informs (February 2001), pp.10-11. Or see Nancy Burrows, "The World March of Women at the World Social Forum in Porto Alegre" (2002), available: <http://www.ffq.qc.ca/marche2000/en/fsm2002b.html>. Arguably, the interventions of such groups have made an impact on the declarations associated with the Forum which increasingly pay attention to the intersections of neoliberalism with gendered and racialised hierarchies, See Call of Social Movements "Resistance to Neoliberalism War and Militarism: For Peace and Social Justice" (2002), available: $<\mathrm{http}$ ://www.forumsocialmundial.org.br/dinamic/eng portoalegrefinal.asp $>$. These developments are explored at much greater length in Catherine Eschle, "Skeleton Women: Feminism and Social Movement Resistances to Corporate Power and Neoliberalism", paper presented at the International Studies Association $44^{\text {th }}$ Annual Convention (February 2003), Portland, Oregon, USA.

56. Robertson and Khondker, op. cit.

57. The term "transformationalist" is from David Held et al., Global Transformations, op. cit., drawing attention to the fact these approaches depict globalisation as transformative of social relations and as subject to transformation through human agency. The term "multidimensional" is my own.

58. E.g. Anthony Giddens, The Consequences of Modernity (Cambridge: Polity Press, 1990); Roland Robertson, Globalization: Social Theory and Global Culture, (London: SAGE, 1992); Held et al., Global Transformations, op cit.; David Held and Anthony McGrew (eds.), The Global Transformations Reader, $2^{\text {nd }}$ edition (Cambridge: Polity Press, 2003); Malcolm Waters, Globalization, $2^{\text {nd }}$ edition (London: Routledge, 2001); Appadurai, op. cit.

59. Robertson, Globalization: Social Theory and Global Culture, op. cit., pp. 105-107.

60. Giddens, The Transformation of Intimacy: Sexuality, Love and Eroticism in Modern Societies (Cambridge: Polity Press, 1992); Modernity and Self-Identity: Self and Society in the Late Modern Age (Cambridge: Polity Press, 1991).

61. The relation of these to globalisation is discussed by Giddens in Consequences of Modernity, op. cit., pp. 70-78; but he does not examine their gendered dimensions.

62. Feminist globalisation theorists stressing these two areas of research include Bergeron, op. cit., pp. 990-991; Afshar and Barrientos, "Introduction: Women, Globalization and Fragmentation" in Afshar and Barrientos (eds.), Women, Globalization and Fragmentation, op. cit., pp. 3-4; Marchand, op. cit.

63. Sassen, op. cit., p. 12.

64. E.g. M.P. Fernandez-Kelly, For We are Sold, I and My People: Women and Industry in Mexico's Frontier (Albany, NY: State University of New York Press, 1983); Annette Fuentes and Barbara Ehrenreich, Women in the Global Factory (Boston: South End Press, 1983); Carolyn E. Sachs, Gendered Fields: Rural Women, Agriculture and Environment (Boulder, CO: Westview Press, 1996); Chandra Talpade Mohanty, "Women Workers and Capitalist Scripts: Ideologies of Domination, Common Interests and the Politics of 
Solidarity" in M. Jacqui Alexander and Mohanty (eds.), Feminist Genealogies, Colonial Legacies, Democratic Futures (London: Routledge, 1997); Elisabeth Prügl and Eileen Boris, Homeworkers in Global Perspective: Invisible No More (New York: Routledge, 1996).

65. E.g. Diane Elson “ The Impacts of Structural Adjustment on Women: Concepts and Issues" in Bade Onimode (ed.),The IMF, the World Bank and the Africa Debt, Volume 2: The Social and Political Impact (London: Zed, 1989), pp. 56-74; Valentine M.

Moghadam, "Bringing the Third World In: A Comparative Analysis of Gender and Restructuring" in Valentine M. Moghadam (ed.), Democratic Reform and the Position of Women in Transitional Economies (Oxford: Clarendon Press, 1993); Janine Brodie, "Shifting the Boundaries: Gender and the Politics of Restructuring" in Isabella Bakker (ed.), The Strategic Silence: Gender and Economic Policy (London: Zed Books, 1994).

66. E.g. Elisabeth Prügl, The Global Construction of Gender: Homebased Work in the Political Economy of the Twentieth Century (New York: Columbia University Press, 1999); Wichterich, op. cit.; Jacqui True, Gender, Globalization, and Postsocialism: The Czech Republic After Communism (New York: Columbia University Press, 2003).

67. Runyan and Marchand, "Conclusion: Feminist Approaches to Global Restructuring",op. cit., p. 228, emphasis added.

68. E.g. Valerie Sperling et al. "Constructing Global Feminism: Transnational Advocacy Networks and Russian Women's Activism", Signs: Journal of Women in Culture and Society, Vol. 26, No. 4 (2001), pp. 1155-1186.

69. Gillian Youngs, "Breaking Patriarchal Bonds: Demythologizing the Public/Private" in Marchand and Runyan (eds.), Gender and Global Restructuring, op. cit., pp. 209-224.

70. Charlotte Hooper, "Masculinities in Transition: the Case of Globalization" in Marchand and Runyan (eds.), Gender and Global Restructuring, op. cit., pp. 59-73.

71. See e.g. O'Brien et al. op. cit., and the essays in Meyer and Prügl (eds.), op. cit.

72. Marchand, op. cit., pp. 588-591; Anne Sisson Runyan, "Women in the Neoliberal 'Frame"' in Meyer and Prügl (eds.), op. cit., pp. 210-220.

73. Marchand and Runyan, "Introduction. Feminist Sightings of Global Restructuring: Concptualisations and Reconceptualisations", op. cit., pp. 12-13.

74. Bergeron, op. cit., pp. 997-998.

75. Carla Freeman, "Is Local: Global as Feminine: Masculine? Rethinking the Gender of Globalization", Signs: Journal of Women in Culture and Society, Vol. 26, No. 4 (2001), pp. 1007-1037.

76. Kimberly A. Chang and L.H.M. Ling, "Globalization and its Intimate Other: Filipina Domestic Workers in Hong Kong" in Marchand and Runyan (eds.), Gender and Global Restructuring, op. cit.

77. E.g. Collins, op. cit.; Deborah K. King, "Multiple Jeopardy, Multiple Consciousness: The Context of a Black Feminist Ideology", Signs: Journal of Women in Culture and Society, vol. 14, No. 1 (1988): 42-72; Alexander and Mohanty, eds. Feminist Genealogies, Colonial Legacies, Democratic Futures, op cit. I make this point at more length in Catherine Eschle, Global Democracy, Social Movements and Feminism (Boulder, CO: Westview Press, 2001), chapters four and six.

78. Jahnavi Phalkey, "Right-Wing Mobilization of Women in India: Hindutva's Willing Performers" in Afshar and Barrientos (eds.), op. cit., pp. 38-53. 
79. Seiko Hanochi, "Japan and the Global Sex Industry" in Kelly et al. (eds.), op. cit., pp. 137-146.

80. Janet Kenway with Diana Langmead, "Fast Capitalism, Fast Feminism and Some Fast Food for Thought" in Suki Ali et al. (eds.), Global Feminist Politics: Identities in a Changing World (London: Routledge, 2000), pp. 162-163.

81. There is a notable literature on globalisation, identity and cultural difference within transnational feminist organising, e.g. L. Amede Obiora "Feminism, Globalism and Culture: After Beijing”, Indiana Journal of Global Legal Studies, vol. 4, No. 2(1997), pp. 97-105.

82. Afshar and Barrientos, "Introduction", op. cit., p. 1.

83. Cindi Katz, "On the Grounds of Globalization: A Topography for Feminist Political Engagement", Signs: Journal of Women in Culture and Society, Vol. 26, No. 4 (2001), p. 1214.

84. Chang and Ling, op. cit., p, 31.

85. Roland Robertson, "Glocalization: Time-Space and Homogeneity/Heterogeneity", and Jan Nederveen Pieterse, "Globalization as Hybridization", both in Michael Featherstone, Scott Lash and Roland Robertson (eds.), Global Modernities (London: SAGE, 1995). Glocalisation implies that local social relationships mediate and restructure global forces. Analyses of hybridity highlight the ways in which cultural forms become detached from existing traditions and locations and recombined with other forms in different locations, thus creating something new.

86. Sassen, op. cit., p. 16.

87. Klein, No Logo, op. cit.

88. Freeman, op. cit., p.1031.

89. Ibid..

90. Marchand, op. cit., p. 585.

91. E.g. Cox, op. cit.

92. E.g. Colin Hay, "What Place for Ideas in the Structure-Agency Debate? Globalisation as a 'Process without a Subject'” (2001), available:

$<$ http://www.theglobalsite.ac.uk/press/109hay.htm>; Hirst and Thompson, op. cit.

93. See the critique in Bergeron, op. cit., pp. 990-996. I suggest that the feminist return to the state in the context of restructuring is rooted in nostalgia for social democratic compacts which a) have always had ambivalent effects on women, b) may not be recoverable, and c) are unlikely to be universalisable to many non-western states whose poverty and fragile statehood is partly a product of international systems from which social democratic states drew their strength.

94. Chang and Ling, op. cit., pp. 30-32.

95. Note that feminist use of this terminology reflects a general trend in literature dealing with globalisation and activism. See e.g Jackie Smith and Hank Johnston (eds)

Globalization and Resistance: Transnational Dimensions of Social Movements (Lanham: Rowman and Littlefield, 2002); Christine Chin and James H. Mittleman, "Conceptualizing Resistance to Globalization" in Gills (ed.), op. cit., pp. 29-45.

96. Phalkey, op. cit., p. 47.

97. Chang and Ling, op. cit., p. 42.

98. Freeman, op. cit., p.1031 
99. Stienstra, "Dancing Resistance", op. cit.

100. Higer, op. cit., p. 137.

101. Kathleen Staudt et al. "Protesting World Trade Rules: Can We Talk about Empowerment?", Signs: Journal of Women in Culture and Society, Vol. 26, No. 4 (2001), p. 1256.

102. Sperling et al. op. cit., p. 1182.

103. Explored at more length in Eschle, "Skeleton Women: Feminism and Social Movement Resistances to Corporate Power and Neoliberalism", op. cit. 